\title{
JUDGING FROM VENUS: A RESPONSE TO JOOST PAUWELYN
}

\author{
Gabrielle Marceau, Catherine Quinn, and Juan Pablo Moya Hoyos*
}

In this short response, we offer some additional context to the appointment of government officials as World Trade Organization (WTO) panelists, some information on the role of the Secretariat and areas of cross-fertilization.

\section{The Involvement of Panel Members Working for Government}

Pauwelyn emphasizes that a significant proportion of WTO panel members have a substantial government background. His numbers indicate that for the period 1995-2014, 88 percent of WTO panelists had worked a minimum of "three years in government as diplomats, negotiators, bureaucrats, ministers and so on."1 However, if we look at whether the panelists are employed by governments, either as diplomats or trade specialists, at the time of their appointment as WTO panelists, the figure changes dramatically: only about 50 percent of WTO panelists are employed in government at the time of their nomination. ${ }^{2}$ In accordance with Article 8.9 of the Dispute Settlement Understanding (DSU), the procedural rules applicable to WTO dispute settlement proceedings, panelists serve in their individual capacities and not as government representatives.

The appointment of nongovernmental panel members is a development for the WTO dispute settlement system. During the early years of the General Agreement on Tariffs and Trade (GATT), only governmental officials were nominated as panelists. This practice was based inter alia on GATT Article XXIII, which cryptically provided that any disagreement or dispute between the contracting parties had to be referred to the contracting parties, acting jointly. ${ }^{3}$ Almost all panelists were Geneva-based delegates. In 1979, the contracting parties to the GATT adopted the Understanding regarding Notification, Consultation, Dispute Settlement and Surveillance (1979 Understanding). ${ }^{4}$ The 1979 Understanding confirmed the contracting parties' customary practice of appointing panelists from government, but determined that in a few cases, due to the complexity of the matter, nongovernment experts should be appointed. The 1979 Understanding also expressed the contracting parties' desire to establish an informal indicative list of governmental and nongovernmental panelists

\footnotetext{
* Gabrielle Marceau, Counsellor in the Legal Affairs Division of the WTO, Professor, UNIGE. Catherine Quinn and Juan Pablo Moya Hoyos are Dispute Settlement Lanyers in the Legal Affairs Division of the WTO. Views and opinions expressed in this essay are those of the authors and do not bind WTO Members or WTO Secretariat.

Originally published online 13 April 2016.

1 Joost Pauwelyn, The Rule of Law Without the Rule of Lawyers? Why Investment Arbitrators are from Mars, Trade Adjudicators from Venus, 109 AJIL 761, 772 n. 73 (2015). He also notes that 72\% of Appellate Body Members appointed to date were also members of the public service.

${ }^{2}$ On average, over the last ten years.

${ }^{3}$ For more information, see generally Historic development of the WTO dispute settlement system, WorLD TRADE OrGANIZATION.

${ }^{4}$ GATT Understanding regarding Notification, Consultation, Dispute Settlement and Surveillance, Annex, para. 6 (iii), GATT Doc. L/4907 (Nov. 28, 1979).
} 
"qualified in the fields of trade relations, economic development, and other matters covered by the General Agreement, and who could be available for serving on panels." ${ }^{5}$ In 1982 the GATT Council of Representatives issued a report in which they indicated the need to make greater use of outside experts in panel proceedings: "In respect of the panel procedures ... [g]reater use should be made of outside experts having up-to-date knowledge of the functioning of GATT; and panel members' qualifications should be more clearly defined." 6

This historical background explains in part the considerable number of WTO panelists who work or have worked for government. From its inception, the idea behind the GATT dispute settlement system was that if there were any issues in the implementation or interpretation of the GATT, these would be resolved by the contracting parties themselves, working together. Evidently, this approach has influenced the development and evolution of the WTO dispute mechanism. ${ }^{7}$ Of course, the idea that contracting parties would sort out any problems "amongst themselves" is a concept that differs drastically from one of the central tenets of arbitration: the desire to entrust the resolution of a dispute to a neutral third party, i.e., an outsider.

\section{New Fee Structure for Nongovernmental and Governmental Panelists}

According to Pauwelyn, the significant presence of governmental officials among WTO panelists correlates with the relatively small participation of individuals having "substantial experience in private law firms," which he defines as having a minimum of "three years of experience with a law firm either before or after the WTO appointment." " Based on these criteria, Pauwelyn finds that only 15 percent of WTO panelists have this type of experience, while 76 percent of International Centre for the Settlement of Investment Disputes (ICSID) arbitrators do. ${ }^{9}$ He notes that the low remuneration paid to nongovernmental panelists might be a factor behind the limited involvement of private lawyers as panel members. ${ }^{10}$

Until the 1980s panelists were government officials paid by their government with no additional remuneration for panel work. The question of panelists' remuneration started to surface with the participation of nongovernmental panelists. In 1982, the GATT contracting parties adopted a Ministerial Declaration addressing this issue. ${ }^{11}$ The contracting parties decided that in situations where panelists were not chosen from the parties' delegations in Geneva, their expenses would be covered by the GATT budget. The Ministerial Declaration states: "With reference to paragraph 13 of the Understanding, contracting parties will co-operate effectively with the Director-General in making suitably qualified experts available to serve on panels. Where experts are not drawn from Geneva, any expenses, including travel and subsistence allowance, shall be met from the GATT budget."12

It was about the same time that contracting parties started paying fees to nongovernmental panelists, in addition to their expenses. In 1983, the fee for nongovernmental panelist was CHF500. In 1993, it was increased to $\mathrm{CHF600.}$

${ }^{5} \underline{I d}$. at para. 13 .

${ }^{6}$ GATT Council of Representatives, Report on Work since the 37th Session, 7, GATT Doc. L/5414 (Nov. 12, 1982).

${ }^{7}$ On the reasons for the common use of current or former governmental individuals as WTO panelists, see also Reto Malacrida, WTO Panel Composition: Searching Far and Wide for Administrators of World Trade Justice, in A HiSTORY OF LAW AND LAWYERS IN THE GATT/WTO: The Development of the Rule of LaW in the Multilateral Trading System 311, 324, $330-331$ (Gabrielle Marceau ed., 2015).

8 Pauwelyn, supra note 1 , at 773.

${ }^{9} \underline{I d}$. at $772-773$.

${ }^{10} \underline{I d}$. at 791 .

11 GATT Contracting Parties, 38th Session, Ministerial Declaration, GATT Doc. L/5424 adopted on (Nov. 29, 1982).

${ }^{12} \underline{I d}$. at 7 . 
At the end of 2015, the W'TO General Council decided to increase the daily fees of nongovernmental panelists from CHF600 to CHF900 (as of 1 January 2016). ${ }^{13}$ In addition, it was also decided that governmental panelists could now claim CHF300 for each full day of panel work. WTO adjudicators, including Appellate Body members, are assisted by legal officers and other experts from the Secretariat. Therefore, WTO adjudicators do not need, and are not allowed to, hire legal assistants or secretaries to help them discharge their adjudicatory work. It remains to be seen if the new fee structure will have the effect of diversifying appointment patterns.

\section{The Geographical Diversity and Representativeness of WTO Panel Members Under the DSU}

Pauwelyn rightly notes that WTO panels are characterized by a high level of geographical diversity and representativeness. His numbers indicate that 52 percent of panelists are nationals of developing countries. ${ }^{14}$ This differs greatly from the data found in investment arbitrations, where 69 percent of ICSID arbitrators are from Northern America and Western Europe combined. ${ }^{15}$ Pauwelyn warns that these numbers come with caveats. First, the term "developing countries" is rather broad at the WTO. There is no standing definition of "developing" or "developed" country in the WTO legal system.

Second, the identity of the disputing parties also has an effect on the nationality of the WTO adjudicators. In accordance with Article 8.3 of the DSU, nationals of parties or third parties to the dispute cannot serve as panelists, unless the parties to the disputes agree. Since the majority of disputes involve the European Union and the United States as disputing parties or third parties, no nationals from these two WTO Members can act as panelists in these disputes without the agreement of the parties. DSU Article 8.3 has created many opportunities for developing country panelists to be involved in WTO adjudication. For example, the United States/Canada-Continued Suspension cases, between the European Communities, the United States, and Canada, were adjudicated by panels composed entirely of individuals from developing countries. ${ }^{16}$

Interestingly, the DSU expressly provides that in some cases, panelists from developing countries are to be appointed. Article 8.10 states that: "When a dispute is between a developing country member and a developed country Member the panel shall, if the developing countries so requests, include at least one panelist from a developing country Member."

This provision is extremely important, given that 68 percent of cases filed at the WTO at first instance involve at least one developing country. ${ }^{17}$

A provision similar to Article 8.10 could be introduced in investor-state arbitration Since the arbitrating parties already have the possibility to appoint their own arbitrator, the provision could be addressed to the appointing authority responsible for nominating an arbitrator when a party fails to appoint one. ${ }^{18}$ Given that according to Pauwelyn, 83 percent of investment cases are brought against developing countries, a strong legal

${ }^{13}$ Nongovernmental and governmental panelists both receive a per diem in accordance with United Nations standard rates.

14 Pauwelyn, supra note 1 , at 771 .

${ }^{15} \underline{I d}$. at 770 .

16 Panel Report, United States_Continued Suspension of Obligations in the EC-Hormones Dispute, WT/DS320/R (Adopted Nov. 14, 2008); Panel Report, Canada-Continued Suspension of Obligations in the EC-Hormones Dispute, WT/DS321/R (Adopted Nov. 14, 2008).

${ }_{17}$ Pauwelyn, supra note 1 , at 771 n. 63.

${ }^{18}$ The Chairman of the ICSID Administrative Council (the President of the World Bank) under Article 38 of the ICSID Convention or the individual agreed to by the disputing parties or designated by the Secretary-General of the Permanent Court of Arbitration under Article 6 of the 2010 UNCITRAL Arbitration Rules. 
push for the appointment of arbitrators coming from developing countries in cases involving such countries could change the appointment landscape significantly.

\section{The Role of the Secretariat}

Pauwelyn also highlights the strong role of the WTO Secretariat in providing legal and administrative assistance to panels and Appellate Body members. This is especially so compared to the relatively smaller role that the ICSID Secretariat plays in the course of investment proceedings. ${ }^{19}$ The dispute resolution functions performed by the WTO Secretariat are expressly mandated by the DSU. Article 27(1) states that the Secretariat has "the responsibility of assisting panels, especially on the legal, historical and procedural aspects of the matters dealt with." To discharge these functions, the WTO Secretariat is divided into two legal divisions: the Legal Affairs Division and the Rules Division. These two divisions assist first instance panels, with the Rules Division specializing with subsidies, antidumping and safeguards disputes. The Appellate Body also has its own Secretariat providing it with legal support. In total, sixty-eight lawyers are currently servicing these three divisions. There are twenty-six on-going panels, including appeals. In practice, each panel is allocated a senior lawyer, a junior lawyer or more depending on the complexity of the case, and a jurist or advisor from one of the specialised divisions of the organization (for example, Market Access or Agriculture).

The high volume of disputes recently filed at the WTO has created a shortage of Secretariat staff able to assist panels. This is especially true in the Rules Division, which currently has the most disputes. Evidently, this situation has created delays in the settlement of disputes. While these delays are not long compared to delays in other international tribunals, Members have voiced their concern over the increased length of proceedings. Although it has been suggested that panels could proceed without any Secretariat assistance, this approach has not been explored further. The Members have instead decided to wait for the Secretariat staff to become available. WTO dispute settlement is paid for by the entire WTO membership, out of the Members' contributions; unlike ICSID the WTO does not charge for its dispute settlement services.

As part of recent regional trade agreements, a number of countries have begun pursuing options for further strengthening, institutionalizing, and multilateralizing investment dispute settlement mechanisms. Such is the case, for example, with the Comprehensive Economic and Trade Agreement (CETA) between Canada and the European Union, and the Free Trade Agreement between the European Union and Vietnam. The European Union also proposed to establish an investment court with the United States in the context of the Transatlantic Trade and Investment Partnership (TTIP). ${ }^{20}$ The CETA provides that the Secretariat of ICSID would be acting as Secretariat for the court and the cost of dispute settlement would be paid by the parties to CETA. The role of the Secretariat, in particular for the Appeal Tribunal, is yet to be to be determined by the CETA Joint Committee. Very interestingly, the CETA parties have agreed to "pursue with other trading partners the establishment of a multilateral investment tribunal and appellate mechanism for the resolution of investment disputes." 22

\footnotetext{
${ }_{19}$ Pauwelyn, supra note 1, at 795-796.

20 The text proposed by the European Union dated 12 November 2015 is available at Trade, EuropeAn COMmission.

22 Article 8.27-8.28
} 


\section{Cross-Fertilization: Past Experience and Lessons to be Drawn}

There is a broader theme touched upon by Pauwelyn: the cross-fertilization, or absence thereof, between international trade law and international investment law. ${ }^{23}$ Better understanding the interaction and relationship between the two legal regimes is important, since trade disputes can lead to actions or retaliation affecting investments, and investment arbitration disputes can involve trade discrimination.

From a substantive perspective, informed cross-fertilization between the two fields of international trade law and investment law is limited. At the WTO, panel and Appellate Body members have on certain occasions drawn from the jurisprudence of international investment tribunals. In China-Rare Earths, for example, the Panel referred to the MTD v. Chile ruling on the meaning of fair and equitable treatment to inform its interpretation of the even-handedness requirement under GATT Article XX $(\mathrm{g}) \cdot{ }^{24}$ In the course of the same analysis, the Panel also referred to the partial award in Saluka v. Crech Republic, and noted that investment arbitration tribunals "have been willing to show a degree of deference to the fact that governments have the right to choose the way in which they resolve national problems." 25 In United States-Stainless Steel (Mexico), the Appellate Body cited Saipem v. Bangladesh to rule on the question of precedent in WTO proceedings, stating that "absent cogent reasons, an adjudicator body will resolve the same legal question in the same way in a subsequent case." 26 However, beyond a limited number of other examples, ${ }^{27}$ reliance on international investment jurisprudence in WTO case law remains sparse.

Perhaps the proliferation of megaregional trade agreements incorporating WTO obligations will have the effect of increasing convergence in the future. For example, CETA incorporates GATT Article XX in the Exceptions Chapter. The incorporated exceptions apply to certain investment obligations contained in the Investment Chapter of the Agreement, specifically those relating to the establishment of investments and nondiscriminatory treatment. ${ }^{28}$ It can easily be envisaged that substantive cross-fertilization will occur when disputes are brought under the Investment Chapter, as disputing parties will most likely refer to the lengthy and important WTO jurisprudence on GATT Article XX in their pleadings.

From a procedural perspective, the WTO could learn from the use of experts in investment arbitration. At the WTO, experts involved in dispute settlement do not appear as expert-witnesses providing expert testimony. During hearings, experts are part of of the national delegations of the disputing W'TO Members. There is no

23 Pauwelyn, supra note 1, at 761-762. See also, Stephan W. Schill, US versus EU Leadership in Global Investment Governance, J. WORLD INV. \& TRADE (2016).

24 Panel Report, China-Measures Related to the Exportation of Rare Earths, Tungsten and Molybdenum, para. 7.319, WT/DS431/R, WT/DS432/R, WT/DS433/R (Adopted Aug. 29, 2014).

${ }^{25} \underline{I d}$. at para. 7.322 .

26 Appellate Body Report, United States-Final Anti-Dumping Measures on Stainless Steel from Mexico, para. 160, n. 313, WT/DS344/AB/R (Adopted May 20, 2008).

${ }^{27}$ In United States-1916 (Act) (EC), the Appellate Body referred to ICISD Arbitration Rule 41(2) in support of its statement that certain questions of jurisdictions can be raised at any time during the proceedings (Appellate Body Report, United States-Anti-Dumping Act of 1916, para. 54, n. 30, WT/DS136/AB/R (Adopted Sep. 26, 2000). Investment arbitration awards have been cited by disputing parties and third parties in support of their argument: see Panel Report, Colombia-Measures Relating to the Importation of Textiles, Apparel and Footwear, para. 7.64, n. 155, WT/DS461/R (Circulated Nov. 27, 2015); Panel Report, United States-Measures Affecting the Cross-Border Supply of Gambling and Betting Services, Annex C, C-9, n. 151, WT/DS285/R (Adopted Apr. 20, 2005). In some cases, disputing parties have referred to general practice at ICSID: see Panel Report, United States-Anti-Dumping Measures on Shrimp from Ecuador, Annex C-15, C-25, n. 1, WT/DS335/R (Adopted Feb. 20, 2007); First Written Submission of the European Union in Panel Report, United States_Continued Existence and Application of Zeroing Methodology, Annex A, A-23, para. 82, n. 79, WT/DS350/R (Adopted Feb. 19, 2009).

28 See Draft Article X.02 (General Exceptions) of Comprehensive and Economic Trade Agreement between the European Union and Canada available at Global Affairs Canada, Consolidated CETA Text, GovernMENT OF CANADA (2014). 
formal examination or cross-examination procedure. Expert-delegates participate in the proceedings as the parties wish. They may directly address the panel if invited to do so by the disputing party, or they may convey their response to disputing party's lawyer who presents their answer to the panel. In certain circumstances, it could be helpful for the disputing parties to present their experts as expert-witnesses, subject to cross-examination. This could lead to more in-depth questioning, thereby allowing WTO panels to better distil possible areas of agreement or disagreement in the expert evidence submitted by the parties. It has been suggested that since the WTO dispute settlement system is a government-to-government mechanism, it would be inappropriate to "cross-examine a state." However, experts presented by respondent states get cross-examined in investment arbitration as well as in cases before the International Court of Justice. Furthermore, in situations where panels have appointed their own experts, ${ }^{29}$ the questioning by the panel at the hearing could extend to these experts as well.

\section{Conclusion}

The above demonstrates that there is potential in the future for more interaction between the fields of investment arbitration and WTO dispute settlement proceedings. The nature of this interaction will be a result of different factors, including the identity of panelists and arbitrators and the different trade and investment agreements involved. It will also depend on the extent to which the disputing parties themselves decide to invoke the norms and jurisprudence of one field when pleading a dispute in the other. This could be where fertile ground for future development lies.

${ }^{29}$ In accordance with Article 13 of the DSU. 